\title{
BITNA POVREDA MEĐUNARODNOG UGOVORA NA PRIMJERU ARBITRAŽNOG SPORAZUMA IZMEĐU HRVATSKE I SLOVENIJE
}

DOI: 10.3935/zpfz.69.4.05

Pregledni znanstveni rad Primljeno: lipanj 2019.

U radu se utvrduje postojanje bitne povrede Arbitražnog sporazuma između Hrvatske i Slovenije u smislu članka 60. Bečke konvencije o pravu međunarodnih ugovora iz 1969., a samim time i opravdanost hrvatskog zahtjeva za prestankom Arbitražnog sporazuma. Naime, člankom 60. Bečke konvencije predvidena je mogućnost prestanka međunarodnog ugovora u slučaju njegove bitne povrede. S obzirom na to da je postojanje bitne povrede ključni uvjet za stjecanje prava na jednostrani raskid ugovora, razmatra se pojam bitne povrede, pri čemu se poseban naglasak stavlja na kriterije bitne povrede koji su predvideni člankom 60. Bečke konvencije. Na temelju toga analizira se čini li djelovanje Slovenije, odnosno ex parte komunikacija u arbitraži između Hrvatske i Slovenije, odbacivanje Arbitražnog sporazuma ili pak povredu odredbe bitne za ostvarenje njegova predmeta $i$ svrhe. Zaključno, $u$ radu se tvrdi da je Slovenija bitno povrijedila Arbitražni sporazum u smislu članka 60. Bečke konvencije.

Ključne riječi: bitna povreda, međunarodni ugovor, ex parte komunikacija, Arbitražni sporazum između Hrvatske i Slovenije

\footnotetext{
Dr. sc. Ljubo Runjić, viši predavač Veleučilišta u Šibeniku, Trg Andrije Hebranga 11, Šibenik,runjic@vus.hr;

ORCID ID: orcid.org/0000-0002-1500-2717
} 


\section{UVOD}

Bitna povreda međunarodnog ugovora jedno je od najkontroverznijih pitanja iz područja prava međunarodnih ugovora. Premda je spomenuto pitanje uređeno člankom 60. Bečke konvencije o pravu međunarodnih ugovora iz 1969. (dalje u tekstu: Bečka konvencija) ${ }^{1}$ te pri tome temeljito obrađeno u međunarodnopravnoj doktrini ${ }^{2}$, primjeri iz prakse potvrđuju nam da još postoje ozbiljna neslaganja u tumačenju i primjeni članka 60. Bečke konvencije. ${ }^{3}$ Upravo do takvog neslaganja došlo je nakon javnog razotkrivanja ex parte komunikacije u arbitraži između Hrvatske i Slovenije.

1 Za tekst Konvencije vidi United Nations Treaty Series, sv. 1155, 1980., str. 331; hrv. prijevod u: Narodne novine - Međunarodni ugovori, br. 16/1993; također u: Lapaš, D.; Šošić, T. M. (ur.), Medunarodno javno pravo: izbor dokumenata, Pravni fakultet u Zagrebu, Zagreb, 2005., str. 71.

2 Vidi Crnić-Grotić, V., Pravo međunarodnih ugovora, Pravni fakultet Sveučilišta u Rijeci, Rijeka, 2002., str. 260 - 274; Fitzmaurice, M., Material Breach of Treaty: Some Legal Issues, Austrian Review of International and European Law, sv. 6, 2001., str. 3 - 44; Giegerich, T., Article 60. Termination or Suspension of the Operation of a Treaty as a Consequence of its Breach, u: Dörr, O.; Schmalenbach, K. (ur.), Vienna Convention on the Law of Treaties: A Commentary, Springer, Berlin, 2018., str. 1095 - 1125; Gomaa, M. M., Suspension or Termination of Treaties on Grounds of Breach, Martinus Nijhoff, The Hague - Boston, 1996.; Kirgis Jr., F. L., Some Lingering Questions about Article 60 of the Vienna Convention on the Law of Treaties, Cornell International Law Journal, sv. 22, 1989., str. 549 - 573; Rosenne, S., Breach of Treaty, Cambridge University Press, Cambridge, 1985.; Simma, B., Reflections on Article 60 of the Vienna Convention on the Law of Treaties and its Background in General International Law, Österreichische Zeitschrift für öffentliches Recht, sv. 20, 1970., str. 5 - 83; Simma, B.; Tams, C. J., Article 60: Termination or Suspension of the Operation of a Treaty as a Consequence of its Breach, u: Corten, O.; Klein, P. (ur.), The Vienna Conventions on the Law of Treaties: A Commentary, sv. II, Oxford University Press, Oxford, 2011., str. 1351 - 1378; Villiger, M. E., Commentary on the 1969 Vienna Convention on the Law of Treaties, Martinus Nijhoff Publishers, Leiden - Boston, 2009., str. 738 - 751.

3 Pogled na međunarodnu sudsku praksu nakon usvajanja Bečke konvencije otkriva nam nekoliko sporova koji su se među ostalim odnosili i na neslaganje u tumačenju i primjeni čl. 60. Bečke konvencije. Vidi npr. Appeal Relating to the Jurisdiction of the ICAO Council (India v. Pakistan), Judgment, I.C.J. Reports, 1972., str. 46; Case concerning the Air Service Agreement of 27 March 1946 between the United States of America and France, Decision of 9 December 1978, UNRIAA, sv. 18, str. 417; Gabčikovo-Nagymaros Project (Hungary v. Slovakia), Judgment, I.C.J. Reports, 1997., str. 7; Application of the Interim Accord of 13 September 1995 (the former Yugoslav Republic of Macedonia v. Greece), Judgment, I.C.J. Reports, 2011., str. 644; Arbitration Between the Republic of Croatia and the Republic of Slovenia, PCA Case No. 2012-04, Partial Award, 30 June 2016. 
Spor, odnosno neslaganje u tumačenju i primjeni članka 60. Bečke konvencije, nastao je tako između Hrvatske i Slovenije u vezi sa Sporazumom o arbitraži između Vlade Republike Hrvatske i Vlade Republike Slovenije (dalje u tekstu: Arbitražni sporazum), na temelju kojeg se vodio arbitražni postupak. ${ }^{4}$ Naime, Hrvatska je tvrdila da je Slovenija bitno povrijedila Arbitražni sporazum u smislu članka 60. Bečke konvencije telefonskim razgovorima svojeg zastupnika pred Arbitražnim sudom s jednim od članova Arbitražnog suda za vrijeme trajanja arbitražnog postupka. ${ }^{5} \mathrm{~S}$ druge strane, Slovenija je zauzela dijametralno suprotno stajalište te negirala postojanje bitne povrede Arbitražnog sporazuma u smislu članka 60. Bečke konvencije. ${ }^{6}$

Svrha je ovog rada dati odgovor na pitanje postojanja bitne povrede Arbitražnog sporazuma od strane Slovenije u smislu članka 60. Bečke konvencije, a samim time i opravdanosti hrvatskog zahtjeva za prestankom Arbitražnog sporazuma. U tu svrhu prvo ćemo razmotriti pojam "bitne povrede" međunarodnog ugovora u međunarodnom pravu, odnosno spomenuti članak 60. Bečke konvencije. Osim toga, analizirat ćemo i postupak za utvrđivanje prestanka ili suspenzije međunarodnog ugovora zbog njegove bitne povrede koji je predviđen Bečkom konvencijom. Potom ćemo pažnju usmjeriti na $e x$ parte komunikaciju koja se dogodila u arbitraži između Hrvatske i Slovenije te odredbe Arbitražnog sporazuma koje su tom komunikacijom bile povrijeđene. Međutim, kako bismo utvrdili jesu li te povrede ujedno i bitne povrede Arbitražnog sporazuma, ključna će biti ispravna primjena kriterija bitne povrede koji su predviđeni u članku 60., stavku 3. Bečke konvencije. Drugim riječima, ispitat ćemo je li ex parte komunikacijom odbačen Arbitražni sporazum ili pak povrijeđena odredba bitna za ostvarenje njegova predmeta i svrhe. Naposljetku, u radu ćemo dati i kratak osvrt na djelomičnu presudu Arbitražnog suda iz 2016. u onom dijelu koji se odnosi na pitanje bitne povrede Arbitražnog sporazuma od strane Slovenije.

4 Za tekst Sporazuma vidi United Nations Treaty Series, sv. 2748, 2015., str. 3; hrv. prijevod u: Narodne novine - Međunarodni ugovori, br. 12/2009.

5 Vidi Note verbale from the Ministry of Foreign and European Affairs of the Republic of Croatia to the Ministry of Foreign Affairs of the Republic of Slovenia, Note No. 3303/2015, 30 July 2015, http://www.mvep.hr/files/file/dokume nti/arbitraza/ hr/150820-note-verbale-no-3303-2015-(to-the-republic-of-slovenia).pdf (1. srpnja 2019.).

6 Vidi Arbitration Between the Republic of Croatia and the Republic of Slovenia, PCA Case No. 2012-04, Partial Award, 30 June 2016, str. 33, para. 129. 


\section{POJAM BITNE POVREDE}

Sukladno općem načelu prava pacta sunt servanda, koje je kodificirano i Bečkom konvencijom o pravu međunarodnih ugovora, svaki ugovor koji je na snazi veže stranke i one ga moraju izvršavati u dobroj vjeri. ${ }^{7}$ Međutim, unatoč činjenici da je upravo to načelo "kamen temeljac" prava međunarodnih ugovora ${ }^{8}$, u praksi su zabilježena česta kršenja međunarodnih ugovora. ${ }^{9}$ Štoviše, usporedno s konstantnim rastom broja sklopljenih međunarodnih ugovora, koji danas praktički pokrivaju sva područja međunarodne suradnje, rastao je i broj njihovih kršenja.

\subsection{Pravo na jednostrani raskid međunarodnog ugovora}

Kao odgovor na kršenja međunarodnih ugovora međunarodno pravo prihvatilo je načelo inadimplenti non est adimplendum sukladno kojem jedna stranka ima pravo da jednostrano raskine ugovor zbog njegova kršenja od strane druge stranke. ${ }^{10}$ Potvrdu toga nalazimo u praksi država koje su se stoljećima služile pravom na jednostrani raskid ugovora kao odgovorom na njegovo prethodno kršenje od druge strane. ${ }^{11}$ Potrebu priznanja i primjene spomenutog načela prepoznala je i međunarodnopravna doktrina ${ }^{12}$, a slično stajalište nalazimo i

7 Vidi čl. 26. Bečke konvencije.

8 Sličnog stava bila je i Komisija za međunarodno pravo prilikom kodifikacijskog rada na materiji prava međunarodnih ugovora. Vidi Yearbook of the International Law Commission, sv. II, 1966., str. 211. Whitton pak ističe: "The maxim pacta sunt servanda - pacts must be executed in good faith - is nothing less then the keystone of the arch of international society." Whitton, J. B., The Sanctity of Treaties (Pacta Sunt Servanda), International Conciliation, sv. 16, 1934./1935., str. 395. Vidi i McNair, A., Law of Treaties, Clarendon Press, Oxford, 1961., str. 493.

9 Usp. Simma, B.; Tams, C. J., Reacting against treaty breaches, u: Hollis, D. B. (ur.), The Oxford Guide to Treaties, Oxford University Press, Oxford, 2012., str. 576.

10 Vidi npr. Crnić-Grotić, op. cit. u bilj. 2, str. 264; Gomaa, op. cit. u bilj. 2, str. 117; Sinha, B. P., Unilateral Denunciation of Treaty Because of Prior Violations of Obligations by Other Party, Martinus Nijhoff, The Hague, 1966., str. 35; Simma, Tams, op. cit. u bilj. 2, str. 1355.

11 Detaljnije o praksi država i pravu na jednostrani raskid ugovora vidi u: Sinha, op. cit. u bilj. 10, str. $104-193$.

12 Usp. Crnić-Grotić, op. cit. u bilj. 2, str. 262 - 265; Giegerich, op. cit. u bilj. 2, str. 1099; Greig, D. W., Reciprocity, Proportionality and the Law of Treaties, Virginia Journal of International Law, sv. 34, 1995., str. 400; Sinha, op. cit. u bilj. 10, str. $214-215$; Sinclair, I. M., The Vienna Convention on the Law of Treaties, Manchester University Press, Manchester, 1973., str. 103. Vidi također: Yearbook of the International Law Commission, sv. II, 1966., str. 253 - 254. 
u relevantnoj međunarodnoj sudskoj praksi. Primjerice, 1925. u arbitraži Tacna-Arica, između Čilea i Perua, arbitar Coolidge ustvrdio je da su ugovorom iz 1883. stranke predvidjele da sklope poseban protokol te da "namjerno odbijanje bilo koje od stranaka da to izvrši opravdava drugu stranku da traži oslobođenje od te odredbe". ${ }^{13}$ Prema mišljenju Coolidgea do prestanka ugovora moglo je pri tome jedino doći u slučaju da je kršenje ugovorne odredbe onemogućilo ostvarenje svrhe ugovora, što se pak u konkretnom slučaju nije dogodilo. ${ }^{14} \mathrm{U}$ parnici o Preusmjeravanju vode iz Meusea između Nizozemske i Belgije koji se vodio pred Stalnim sudom međunarodne pravde suci Anzilotti i Hudson izričito su podržali načelo inadimplenti non est adimplendum. Anzilotti je tom prilikom $\mathrm{u}$ svojem izdvojenom mišljenju istaknuo sljedeće: "Ja zaista nemam sumnje da je načelo na kojem se temelji ovaj zaključak (inadimplenti non est adimplendum) tako pravedno, tako pravično, tako općepriznato, da mora biti također primijenjeno i u međunarodnim odnosima. U svakom slučaju, to je jedno od onih 'općih načela prava priznatih od civiliziranih naroda' koje Sud primjenjuje na temelju članka 38. svojeg Statuta."15

Premda je pravo na jednostrani raskid ugovora zbog njegova kršenja od strane druge stranke postalo dio međunarodnog običajnog prava, i dalje su ostala brojna nerazjašnjena pitanja vezana uz njegovu primjenu. ${ }^{16} \mathrm{U}$ prvom redu, bilo je dvojbeno daje li svaka povreda ugovora pravo oštećenoj stranci na jednostrani raskid ugovora. Naime, neki su pisci, polazeći od načela pacta sunt servanda i njime proklamirane "svetosti" ugovora, smatrali da svaka povreda ugovora, pa tako i ona najmanja, daje oštećenoj stranci pravo na jednostrani raskid ugovora. ${ }^{17}$ Drugi

13 Tacna-Arica question (Chile v. Peru), Opinion and Award of 4 March 1925, UNRIAA, sv. II, str. 929.

14

15 (inadimplenti non est adimplendum) soit si juste, si équitable, si universellement reconnu qu'il doive être appliqué aussi dans les rapports internationaux. Il s'agit, en tout cas, d'un de ces 'principes généraux de droit reconnus par les nations civilisées' que la Cour applique en vertu de l'article 38 de son Statut." Diversion of water from the Meuse (Netherland v. Belgium), Judgment, P.C.I.J. 1937 (Series A/B), No. 70, str. 50. Slično je razmišljao i sudac Hudson; vidi ibid., str. 77.

16

Te prepoznala i Komisija za medunarodno pravo prilikom svojega rada na kodifikaciji prava međunarodnih ugovora; vidi Yearbook of the International Law Commission, sv. II, 1966., str. 254. Vidi i Brownlie, I., Principles of Public International Law, Oxford University Press, Oxford, 2008., str. 622; Crnić-Grotić, op. cit. u bilj. 2, str. 264; Simma, Tams, op. cit. u bilj. 2, str. 1355 - 1356; Sinclair, op. cit. u bilj. 11, str. 103.

17 Još od vremena Huga Grotiusa mnogi pisci smatrali su da kršenje bilo koje odredbe ugovora daje oštećenoj stranci pravo na jednostrani raskid ugovora. Usp. Brierly, J. 
su pak smatrali da samo kvalificirana povreda daje oštećenoj stranci pravo na jednostrani raskid ugovora ${ }^{18}$, odnosno smatralo se da jedino "bitna" (material) ili "temeljna" (fundamental) povreda ugovora ovlašćuje oštećenu stranku da se pozove na tu povredu kao uzrok prestanka ugovora. Zanimljivo je u tom kontekstu spomenuti i Harvardski nacrt konvencije o pravu međunarodnih ugovora iz 1935., jedan od prvih pokušaja kodifikacije prava međunarodnih ugovora, koji uopće nije predviđao pravo na jednostrani raskid ugovora, nego mogućnost da oštećena stranka, neovisno o karakteru povrede, zatraži od nadležnog međunarodnog suda ili vlasti izjavu o tome da ju je ugovor prestao obvezivati. ${ }^{19}$

Početkom 20. stoljeća velik dio pisaca još je smatrao da svaka povreda ugovora ovlašćuje oštećenu stranku na jednostrani raskid ugovora ${ }^{20}$, međutim prije usvajanja Bečke konvencije prevladavajuće stajalište u doktrini ipak je bilo da oštećena stranka ima pravo na jednostrani raskid ugovora samo u slučaju kvalificirane povrede. ${ }^{21}$ Štoviše, i praksa država prije usvajanja Bečke konvencije

L., The Law of Nations, Oxford University Press, New York, Oxford, 1960., str. 253; Giegerich, op. cit. u bilj. 2, str. 1099; Gomaa, op. cit. u bilj. 2, str. 6-8; Oppenheim, L. F., International Law: A Treatise, sv. I, Longmans, Green and Co., London - New York - Bombay - Calcutta, 1912., str. 580.

18 Vidi Brownlie, op. cit. u bilj. 16, str. 622; McNair, op. cit. u bilj. 2, str. 478; Sinha, op. cit. u bilj. 2, str. $214-215$.

19 Čl. 27., st. a) Harvardskog nacrta konvencije o pravu međunarodnih ugovora iz 1935. tako glasi: "If a State fails to carry out in good faith its obligations under a treaty, any other party to the treaty, acting within a reasonable time after the failure, may seek from a competent international tribunal or authority a declaration to the effect that the treaty has ceased to be binding upon it in the sense of calling for further performance with respect to such State." Za tekst Nacrta vidi American Journal of International Law, sv. 29 (Suppl.), 1935., str. 657.

20 Usp. Kirgis, op. cit. u bilj. 2, str. 553. Oppenheim tako ističe: "[A] minority makes a distinction between essential and non-essential stipulations of the treaty, and maintains that violation of essential stipulations only creates a right for the other party to cancel the treaty. But the majority of writers rightly oppose this distinction, maintaining that it is not always possible to distinguish essential from non-essential stipulations, that the binding force of a treaty protects non-essential stipulations as well as essential ones, and that it is for the faithful party to consider for itself whether violation of a treaty, even in its least essential parts, justifies the cancelling of the treaty." Oppenheim, op. cit. u bilj. 17, str. 580.

${ }^{21}$ Brierly u svojoj kritici stajališta da svaka povreda ugovora ovlašćuje oštećenu stranku na jednostrani raskid ugovora primjećuje: "[T]his doctrine, applied to any of the more important treaties, would lead to results so startling that it has never been adopted in international practice, and ought equally to be rejected by legal theory. There is an absence of decisive authority on the matter, but common sense seems to impose a distinction between terms which are material to a main object 
potvrdila je postojanja prava oštećene stranke na jednostrani raskid ugovora u slučaju kvalificirane povrede od strane druge stranke. ${ }^{22} \mathrm{Za}$ razliku od prakse država, međunarodna sudska praksa toga vremena nije obilovala sporovima vezanima uz pravo na jednostrani raskid ugovora. Pa ipak, možemo izdvojiti arbitražu Tacna-Arica, u kojoj je arbitar ustvrdio da do prestanka ugovora može doći jedino ako bi se dokazalo da su administrativne zloupotrebe stvorile tako tešku situaciju koja bi onemogućavala svrhu ugovora. ${ }^{23} \mathrm{Na}$ taj način arbitar se priklonio stajalištu prema kojem jedino kvalificirana povreda ovlašćuje oštećenu stranku na jednostrani raskid ugovora.

\section{2. Članak 60. Bečke konvencije o pravu međunarodnih ugovora}

Komisija za međunarodno pravo već je 1949. stavila na dnevni red kodifikaciju prava međunarodnih ugovora te je prilikom rada na spomenutoj materiji također prepoznala potrebu priznanja prava stranke da se pozove na povredu kao na uzrok prestanka ugovora ili suspenzije njegove primjene, ali pod određenim uvjetima. ${ }^{24}$ Naime, Komisija je smatrala da pravo na prestanak ili suspenziju ugovora mora biti ograničeno samo na slučajeve u kojima je povreda ozbiljnog karaktera. ${ }^{25}$ Tako se i Komisija priklonila konceptu kvalificirane povrede, pri čemu je prvotno za kvalificiranu povredu koristila izraz "temeljna" (fundamental ${ }^{26}$, ali je on poslije na prijedlog specijalnog izvjestitelja Waldocka, koji je smatrao da je koncept "temeljne" povrede postavljen previsoko, promijenjen u

and those which are not and between breaches which are serious in themselves and those which are trivial." Brierly, op cit. u bilj. 17, str. 253. Vidi i Gomaa, op. cit. u bilj. 2, str. 9 - 12; McNair, op. cit. u bilj. 2, str. 571; Simma, Tams, op. cit. u bilj. 2, str. 1356; Sinha, op. cit. u bilj. 10, str. $214-215$.

Vidi npr. Simma, Tams, op. cit. u bilj. 2, str. 1356; Sinclair, op. cit. u bilj. 11, str. 103; Shaw, M. N., International Law, Cambridge University Press, Cambridge, 2014., str. 686 - 687; Sinha, op. cit. u bilj. 10, str. $214-215$.

Tacna-Arica question (Chile v. Peru), Opinion and Award of 4 March 1925, UNRIAA, sv. II, str. $943-944$.

Vidi Yearbook of the International Law Commission, sv. II, 1966., str. 254.

Ibid., str. 255.

U svojem drugom izvještaju 1957. specijalni izvjestitelj Fitzmaurice prvi put spominje izraz "temeljna". On tako predlaže: "Fundamental breach of a treaty by one party in an essential particular, going to the root of the treaty obligation, may be a ground on which the other party or parties can claim to terminate or suspend it." Vidi Yearbook of the International Law Commission, sv. II, 1957., str. 30. 
izraz "bitna" (material). ${ }^{27}$ Prema mišljenju Komisije za riječ "temeljna" može se shvatiti da znači da samo kršenje odredbe koja se izravno tiče središnje svrhe ugovora može opravdati drugu stranku da okonča ugovor. ${ }^{28}$ Međutim, Komisija je primijetila da i druge odredbe, koje stranka smatra nužnima za efektivno izvršavanje ugovora, mogu biti vrlo bitne u njezinom poticanju da uopće uđe u ugovor, čak iako te odredbe mogu biti pomoćnog karaktera. ${ }^{29}$

Komisija je konačno 1966. usvojila Nacrt članaka o pravu međunarodnih ugovora, pri čemu je članak 57. Nacrta uz manje izmjene na diplomatskoj konferenciji u Beču 1969. usvojen kao članak 60. Konvencije o pravu međunarodnih ugovora. Članak 60 . Bečke konvencije u stavcima 1. i 2. predviđa tako mogućnost prestanka ili suspenzije ugovora u slučaju bitne povrede.$^{30}$ Stavkom 3. članka 60. određeno je pak da bitnu povredu ugovora čini: a) odbacivanje ugovora koje nije predviđeno Bečkom konvencijom; ili b) povreda odredbe bitne za ostvarenje predmeta ili svrhe ugovora. Stavak 4. predviđa da odredbe ugovora koje se primjenjuju u slučaju povrede imaju prednost, sukladno načelu lex specialis derogat legi generali, u odnosu na prethodne stavke, dok stavak 5. isključuje primjenu stavaka 1. - 3. na odredbe o zaštiti čovjeka što ih sadržavaju ugovori humanitarnog karaktera.

27 Vidi Yearbook of the International Law Commission, sv. II, 1963., str. 76.

28 Vidi Yearbook of the International Law Commission, sv. II, 1966., str. 255.

29 Ibid.

30 Potrebno je pri tome razlikovati pravo na prestanak ili suspenziju ugovora koje proizlazi iz prava međunarodnih ugovora od protumjera koje, proizlazeći iz prava odgovornosti država, također mogu dovesti do suspenzije istog ugovora. Naime, premda su mjere predviđene pravom međunarodnih ugovora i protumjere na prvi pogled slične, budući da je u obama slučajevima riječ o odgovorima oštećene stranke na prethodno kršenje ugovora od strane druge stranke, između njih postoje i razlike koje su određene činjenicom da proizlaze iz dvaju odvojenih pravnih režima - prava međunarodnih ugovora i prava odgovornosti država. Simma tako ističe da su mjere predviđene pravom međunarodnih ugovora pravni lijek koji ima za cilj popraviti situaciju u kojoj je ravnoteža između prava i obveza u ugovornom odnosu bila narušena kršenjem ugovora. S druge strane, protumjere imaju za cilj prisiliti državu kršiteljicu da prestane s kršenjem ugovora te nastavi s njegovim izvršavanjem odnosno nadoknadi eventualnu štetu. Vidi Simma, op. cit. u bilj. 2, str. 20. Odvojenost tih dvaju pravnih režima prepoznala je i Komisija za međunarodno pravo, pa tako čl. 73. Bečke konvencije predviđa da njezine odredbe ne diraju ni u jedno pitanje koje bi, što se tiče ugovora, moglo proizići iz međunarodne odgovornosti država. Više o samim protumjerama vidi u: Lapaš, D., Sankcija u međunarodnom pravu, Pravni fakultet u Zagrebu, Zagreb, 2004., str. 145 - 180; Seršić, M., Međunarodnopravna odgovornost države, Pravni fakultet Sveučilišta u Zagrebu, Zagreb, 2007., str. 53 - 69; Simma, Tams, op. cit. u bilj. 9, str. 595 - 603. 
Nema dvojbe da članak 60. Bečke konvencije velikim dijelom kodificira postojeće međunarodno običajno pravo ${ }^{31}$, međutim u pojedinim pitanjima, poput primjerice koncepta bitne povrede, on predstavlja progresivni razvoj međunarodnog prava. ${ }^{32}$ Štoviše, upravo je koncept bitne povrede sadržan u stavku 3. izazvao najveće prijepore u međunarodnopravnoj doktrini. ${ }^{33}$ To ne čudi s obzirom na to da je koncept bitne povrede ključni element članka 60., odnosno, kako to Giegerich ispravno primjećuje, jedini i nužni uvjet za pokretanje bilo kakvih radnji u pogledu prestanka ili suspenzije ugovora na temelju članka $60 .{ }^{34}$

Stavkom 3. članka 60. definiran je koncept bitne povrede tako da su predviđena dva oblika bitne povrede. Prvi oblik, predviđen točkom a) stavka 3., predstavlja odbacivanje ugovora. Premda članak 60. ne daje definiciju odbacivanja, smatra se da ono obuhvaća sve načine putem kojih se stranka nastoji osloboditi obveza iz ugovora. ${ }^{35} \mathrm{Za}$ razliku od prvog oblika koji nije bio predmetom većih doktrinarnih rasprava s obzirom na to da u pogledu njega nije bilo većih nejasnoća, drugi oblik bitne povrede, predviđen točkom b) stavka 3., bio je izložen kritikama brojnih pisaca. ${ }^{36}$ Naime, članak 60. nije predviđao intenzitet ili težinu povrede odredbe bitne za ostvarenje predmeta ili svrhe ugovora, nego isključivo karakter odredbe koja se krši. Štoviše, kao i u slučaju odbacivanja, članak 60. nije definirao pojam "bitne odredbe" (essential provision). Primjereno tome, doslovnim tumačenjem točke b) stavka 3. svaka povreda odredbe bitne za ostvarenje predmeta ili svrhe ugovora može dovesti do njegova prestanka ili suspenzije. ${ }^{37}$ Drugim riječima, najmanja ili pak trivijalna povreda može dovesti

31 Usp. Giegerich, op. cit. u bilj. 2, str. 1123; Kirgis, op. cit. u bilj. 2, str. 550; Shaw, op. cit. u bilj. 22, str. 687.

32 Usp. Gomaa, op. cit. u bilj. 2, str. 117 - 118; Villiger, op. cit. u bilj. 2, str. 750. Pojedini pisci pak upozoravaju na poteškoće u pravljenju distinkcije između kodifikacije i progresivnog razvoja međunarodnog prava u pogledu čl. 60. Simma tako primjećuje da ni sama Komisija za međunarodno pravo nije imala jasnu sliku o tome što je bilo kodificirano, a što progresivno razvijeno u čl. 60. Vidi Simma, op. cit. u bilj. 2, str. 59.

33 Vidi npr. Fitzmaurice, op. cit. u bilj. 2, str. 3; Kirgis, op. cit. u bilj. 2, str. 551 - 552; Simma, Tams, op. cit. u bilj. 2, str. 1355 - 1356.

Giegerich, op. cit. u bilj. 2, str. 1103.

Vidi UN Doc. A/CONF.39/11 Add. 1., str. 115. Vidi također: Gomaa, op. cit. u bilj. 2, str. 26; Reuter, P., Introduction to the Law of Treaties, Pinter Publishers, London, 1989. str. 161; Simma, Tams, op. cit. u bilj. 9, str. 583. Fitzmaurice, op. cit. u bilj. 2, str. 5 et seq.

Usp. Gomaa, op. cit. u bilj. 2, str. 33; Kirgis, op. cit. u bilj. 2, str. 552; Simma, op. cit. u bilj. 2, str. 61 . 
do prestanka ili suspenzije ugovora ako je riječ o odredbi bitnoj za ostvarenje predmeta i svrhe ugovora. ${ }^{38}$

Pa ipak, pojedini pisci poput Kirgisa, koji se pri tome poziva na zdrav razum, smatraju da minorne povrede odredbi ugovora ne predstavljaju bitnu povredu čak i kad su te odredbe bitne za ugovor. ${ }^{39}$ Sličnog mišljenja je i Giegerich, koji smatra da je očito da točka b) stavka 3. pokriva samo slučajeve u kojima povreda ozbiljno narušava ostvarenje predmeta ili svrhe ugovora, a minorna povreda bitne odredbe prema njemu neće često predstavljati takvu ozbiljnu prijetnju ${ }^{40}$ Štoviše, on ističe da su točka a) i točka b) stavka 3. bili namijenjeni da definiraju povrede iste težine, pa stoga trivijalna povreda bitne odredbe teško može biti proporcionalna odbacivanju ugovora. ${ }^{41}$ Indikativno je da je i Komisija za međunarodno pravo u svojem komentaru nacrta članka 57., koji je postao današnji članak 60 ., jednoglasno zauzela stav da "pravo na prestanak ili suspenziju ugovora mora biti ograničeno na slučajeve gdje je kršenje ozbiljne naravi”. ${ }^{42}$

Unatoč iznesenim stavovima točka b) stavka 3. članka 60. više je nego jasna - svaka povreda odredbe bitne za ostvarenje predmeta ili svrhe ugovora predstavlja bitnu povredu ugovora. Da se pak željelo ograničiti pravo na prestanak ili suspenziju ugovora samo na slučajeve "ozbiljnih" povreda bitnih odredbi, to bi onda bilo i predviđeno člankom 60. Međutim, članak 60. ne govori ništa o minornim ili trivijalnim povredama bitnih odredbi, što pak znači da i one daju oštećenoj stranci pravo da se pozove na njih kao na uzrok prestanka ili suspenzije ugovora. ${ }^{43}$

Pogledamo li pak međunarodnu sudsku praksu nakon usvajanja Bečke konvencije 1969., primijetit ćemo da je ona pokazala visok stupanj konzistentnosti $\mathrm{u}$ pitanju bitne povrede međunarodnog ugovora pozivajući se uglavnom na članak 60 . Bečke konvencije i njime predviđene kriterije za bitnu povredu. ${ }^{44}$

38 Usp. Giegerich, op. cit. u bilj. 2, str. 1106.

39 Kirgis, op. cit. u bilj. 2, str. 552, 555. Vidi i Simma, op. cit. u bilj. 2, str. 61.

40 Giegerich, op. cit. u bilj. 2, str. $1106-1107$.

41 Ibid., str. 1107.

42 Vidi Yearbook of the International Law Commission, sv. II, 1966., str. 255.

43 Gomaa tako ističe: "The silence of Article 60 on minor material breaches cannot be constructed a priori as denying the injured party the right to take measures in response to them. In fact, it is a logical silence since there is no recognition of a separate régime in the law of treaties for so-called "minor material breaches." Gomaa, op. cit. u bilj. 2, str. 121.

44 Vidi npr. Legal Consequences for States of the Continued Presence of South Africa in Namibia (South West Africa) notwithstanding Security Council Resolution 276 (1970), Advisory Opinion, I.C.J. Reports, 1971., str. 47, para. 94; Appeal Relating to the Jurisdiction of 


\subsection{Postupak za utvrđivanje prestanka ili suspenzije međunarodnog ugovora zbog njegove bitne povrede prema Bečkoj konvenciji o pravu međunarodnih ugovora}

Prilikom rada Komisije za međunarodno pravo na pitanjima valjanosti, prestanka i suspenzije međunarodnih ugovora pojedini članovi Komisije, ali i predstavnici država tijekom diplomatske konferencije u Beču izrazili su zabrinutost zbog mogućnosti proizvoljnog tumačenja predloženih uvjeta valjanosti, prestanka i suspenzije međunarodnih ugovora od strane njegovih stranaka. ${ }^{45}$ Prema njima takva mogućnost bila je stvarna opasnost za sigurnost i stabilnost ugovornih odnosa. ${ }^{46}$

Upravo stoga, kako bi spriječila zloupotrebu prava na prestanak ili suspenziju međunarodnog ugovora predviđenog člankom 60. Bečke konvencije, Komisija je predvidjela proceduralne zaštitne mjere protiv mogućnosti da se stranka ugovora proizvoljnim tumačenjem prava na prestanak ili suspenziju ugovora jednostrano oslobodi svojih "neželjenih" ugovornih obveza. Spomenute mjere, sadržane u odjeljku 4. petog dijela Bečke konvencije (članci 65. - 68.) primjenjuju se i glede ništavosti ugovora te povlačenja iz njega.

Već na početku petog dijela Bečke konvencije jasno je propisano člankom 42. da se valjanost ugovora ili pristanka države da bude vezana ugovorom može osporiti samo primjenom Bečke konvencije te da do prestanka ugovora, njegova otkazivanja, suspenzije ili povlačenja iz njega može doći samo primjenom odredaba ugovora ili Bečke konvencije. Iz toga proizlazi da se spomenuti članak, ali i proceduralne mjere glede utvrđivanja ništavosti, prestanka ili suspenzije

the ICAO Council (India v. Pakistan), Judgment, I.C.J. Reports, 1972., str. 67, para. 38; Military and Paramilitary Activities in and against Nicaragua (Nicaragua v. United States of America), Merits, Judgment, I.C.J. Reports, 1986., str. 95, para. 178; str. 138, para. 275-276; Case concerning the difference between New Zealand and France concerning the interpretation or application of two agreements, concluded on 9 July 1986 between the two States and which related to the problems arising from the Rainbow Warrior Affair (France v. New Zealand), Decision of 30 April 1990, UNRIAA, sv. XX, str. 263, para. 100; Gabčikovo-Nagymaros Project (Hungary v. Slovakia), Judgment, I.C.J. Reports, 1997. str. 38, para. 46; str. 62, para. 99; str. 65, para. 106; Application of the Interim Accord of 13 September 1995 (the former Yugoslav Republic of Macedonia v. Greece), Judgment, I.C.J. Reports, 2011., str. 691, para. 163.

45 Vidi Yearbook of the International Law Commission, sv. II, 1966., str. 211.

46 Usp. Prost, M., Article 65: Procedure to Be Followed with Respect to Invalidity, Termination, Withdrawal from or Suspension of the Operation of a Treaty, u: Corten, O.; Klein, P. (ur.), The Vienna Conventions on the Law of Treaties: A Commentary, sv. II, Oxford University Press, Oxford, 2011., str. 1485 - 1486. 
ugovora koje su sadržane u odjeljku 4. petog dijela Bečke konvencije primjenjuju na dvostrane i na mnogostrane ugovore čije su stranke ujedno i stranke Bečke konvencije.

Prema stavku 1. članka 65. Bečke konvencije stranka koja se na temelju odredaba Bečke konvencije pozove na uzrok prestanka ugovora mora svoj zahtjev notificirati ostalim strankama i pri tome navesti mjeru koja se predlaže glede ugovora i razloge za to. Stavkom 2. članka 65. propisano je da ako u roku od tri mjeseca nijedna stranka ne stavi prigovor, stranka koja je izvršila notifikaciju može poduzeti mjeru koju je predložila. Ako bilo koja druga stranka stavi prigovor, između stranaka nastaje spor. Sukladno stavku 3. članka 65. stranke spora moraju tada tražiti rješenje s pomoću sredstva mirnog rješavanja sporova navedenih u članku 33. Povelje Ujedinjenih naroda. ${ }^{47}$ Međutim, stavkom 4. članka 65. predviđeno je da spomenute odredbe članka 65. nisu na štetu prava ili obveza stranaka prema svakoj odredbi koja je između njih na snazi, a koja se tiče rješavanja sporova.

Mnogi članovi Komisije za međunarodno pravo smatrali su da je članak 65. ključan za primjenu cjelokupnog petog dijela Bečke konvencije. ${ }^{48}$ Unatoč tome članak 65. bio je kritiziran od strane velikog broja pisaca, ali i država. I dok u pogledu prvih dviju proceduralnih zaštitnih mjera - obveze notifikacije (stavak 1.) i tromjesečnog moratorija (stavak 2.) nije bilo većih primjedbi, upravo je stavak 3. izazvao najveće rasprave. Naime, većina kritika odnosila se na nepostojanje obveznog sudskog rješavanja sporova u pogledu primjene odredaba Bečke konvencije s obzirom na to da stavak 3. nije podvrgavao, nego samo upućivao stranke spora na sredstva mirnog rješavanja iz članka 33. Povelje Ujedinjenih naroda. ${ }^{49}$ To je imalo za posljedicu da je članak 65. bio jedan od posljednjih članaka usvojenih na Bečkoj konferenciji, i to tek nakon kompromisa koji je

47 Čl. 33., st. 1. Povelje Ujedinjenih naroda navodi sljedeća sredstva mirnog rješavanja sporova: "Stranke svakog spora kojeg bi nastavljanje moglo dovesti u opasnost održavanje međunarodnog mira i sigurnosti moraju prije svega tražiti rješenje pomoću pregovora, ankete, posredovanja, mirenja, arbitraže, sudskog rješavanja, obraćanja regionalnim ustanovama ili sporazumima, ili pomoću drugih mirnih sredstava prema vlastitom izboru." Za tekst Povelje vidi United Nations Treaty Series, sv. 1, 1945., str. XV; hrv. prijevod u: Narodne novine - Međunarodni ugovori, br. 15/ 1993.; ispravak u: br. 7/1994.

48 Vidi Yearbook of the International Law Commission, sv. II, 1966., str. 262.

49 Vidi npr. Briggs, H. W., Procedures for Establishing the Invalidity or Termination of Treaties under the International Law Commission's 1966 Draft Articles on the Law of Treaties, American Journal of International Law, sv. 61, 1967., str. 980; Reisman, W. M., Procedures for Controlling Unilateral Treaty Terminations, American Journal of International Law, sv. 63, 1969., str. $544-545$. 
uvršten u članak 66. Bečke konvencije. Tim člankom predviđeno je da svaka stranka spora o primjeni odredaba Bečke konvencije u pogledu ništavosti i prestanka ugovora zbog suprotnosti s imperativnom normom općeg međunarodnog prava (ius cogens) može, ako se u roku od 12 mjeseci ne postigne rješenje spora na temelju stavka 3. članka 65. podvrgnuti spor jednostranom tužbom Međunarodnom sudu, osim ako se stranke ne bi dogovorile o podvrgavanju spora arbitraži. U svim ostalim slučajevima, pa tako i u slučaju bitne povrede dvostranog ili mnogostranog ugovora, članak 66. upućuje stranke da podnošenjem zahtjeva glavnom tajniku Ujedinjenih naroda pokrenu postupak mirenja naveden u prilogu Bečke konvencije (dalje u tekstu: Prilog).

Spomenuti Prilog, koji također odražava kompromis o obveznom rješavanju sporova glede tumačenja ili primjene petog dijela Bečke konvencije, predviđa uspostavu komisije za mirenje koja bi provodila postupak mirenja s ciljem da se strankama spora predloži obostrano prihvatljivo rješenje spora. Ipak, prijedlozi komisije za mirenje nisu obvezujućeg karaktera, nego su, naprotiv, samo preporuke za rješenje spora koje stranke spora mogu prihvatiti ili odbiti.

Stavkom 1. Priloga predviđeno je da glavni tajnik Ujedinjenih naroda sastavlja i vodi popis miritelja koji čine kvalificirani pravnici, pri čemu svaka država, bilo članica Ujedinjenih naroda bilo stranka Bečke konvencije, nominira dva miritelja. Postupak pred komisijom za mirenje pokreće se upućivanjem zahtjeva glavnom tajniku na temelju članka 66. točke b) Bečke konvencije. Važno je pri tome napomenuti da spomenuti članak ovlašćuje stranke spora da jednostranim zahtjevom pokrenu postupak mirenja. Drugim riječima, postupak pred komisijom za mirenje može biti pokrenut čak i protivno volji druge stranke spora. ${ }^{50} \mathrm{~S}$ obzirom na to da Prilogom nije predviđeno postojanje stalne komisije za mirenje ${ }^{51}$, po zahtjevu podnesenom glavnom tajniku pristupa se sastavljanju ad hoc komisije za mirenje.

Sukladno stavku 2. Priloga svaka stranka spora imenuje dva miritelja na način da jedan miritelj bude državljanin te stranke, neovisno o tome nalazi li se na popisu, dok drugi miritelj ne smije biti državljanin te stranke i mora biti s popisa. Prilogom je određen i vremenski rok imenovanja miritelja od strane stranaka spora, tako da su ih one dužne imenovati u roku od šezdeset dana od datuma kad glavni tajnik primi zahtjev. Nakon toga u roku od šezdeset dana od datuma posljednjeg imenovanja četiri miritelja imenuju s popisa petoga,

50 Usp. Villiger, op. cit. u bilj. 2, str. 822.

51 Usp. Krieger, H., Annex to Article 66., u: Dörr, O.; Schmalenbach, K., (ur.), Vienna Convention on the Law of Treaties: A Commentary, Springer, Berlin, 2018., str. 1247; Villiger, op. cit. u bilj. 2, str. 822 . 
koji je ujedno i predsjedatelj komisije. Prilogom je tako osigurano da je broj članova komisije koji nisu državljani stranaka spora veći od broja onih koji to jesu, čime se je ujedno željela postići i veća objektivnost komisije. ${ }^{52}$ Kako bi se izbjegla pat pozicija u slučaju da se ne obavi imenovanje predsjedatelja komisije ili bilo kojeg drugog miritelja u propisanom roku, Prilogom je predviđeno da ga imenuje glavni tajnik Ujedinjenih naroda u roku od šezdeset dana od proteka tog roka. Glavni tajnik pri tome za predsjedatelja komisije može imenovati bilo koju osobu s popisa ili nekog od članova Komisije za međunarodno pravo. Za pojedine pisce povjeravanje te uloge glavnom tajniku nužan je preduvjet kod obveznog mirenja jer bi u protivnom ono moglo biti potkopano od strane neke od stranaka spora. ${ }^{53}$ Neovisno o spomenutim rokovima za imenovanja, strankama spora ostavljena je mogućnost da sporazumno produže te rokove. Također, u slučaju ispražnjenja mjesta miritelja njegovo popunjavanje se vrši na isti način na koji je prvi put popunjeno.

Stavkom 3. Priloga određeno je da komisija sama propisuje svoj postupak. Također, komisija može pozvati svaku stranku ugovora da joj usmeno ili pismeno iznese svoje stajalište, međutim za to joj je potreban prethodni pristanak stranaka spora. Sve odluke i preporuke komisije prema stavku 3. donose se većinom glasova od ukupnog broja članova komisije. S obzirom na to da komisija ima pet članova za donošenje odluke ili preporuke potrebno je minimalno tri glasa.

Tijekom trajanja postupka komisija saslušava stranke, razmatra njihove zahtjeve i prigovore, te ih pri tome može upozoriti na svaku mjeru koja bi mogla olakšati prijateljsko rješenje. Osim toga, i sama komisija daje prijedloge strankama kako bi se postiglo prijateljsko rješenje spora.

Naposljetku, sukladno stavku 6. Priloga komisija podnosi izvještaj u roku od dvanaest mjeseci od njezina osnivanja. U izvještaju se među ostalim nalaze svi zaključci glede činjenica i pravnih pitanja vezanih uz spor. Kao što je prethodno istaknuto, spomenuti zaključci imaju isključivo karakter preporuka te kao takvi ne obvezuju stranke spora.

52 Rosenne, S., Settlement of Treaty Disputes under the Vienna Convention of 1969, Zeitschrift für ausländisches öffentliches Recht und Völkerrecht, sv. 31, 1971., str. 51.

53 Krieger, op. cit. u bilj. 51, str. 1247. 


\section{EX PARTE KOMUNIKACIJA KAO BITNA POVREDA ARBITRAŽNOG SPORAZUMA?}

\subsection{Ex parte komunikacija u arbitraži između Hrvatske i Slovenije}

Dana 4. studenog 2009. predsjednici vlada Hrvatske i Slovenije potpisali su međunarodni ugovor pod nazivom Sporazum o arbitraži između Vlade Republike Hrvatske i Vlade Republike Slovenije, kojim su Hrvatska i Slovenija podvrgnuli rješavanje svojeg višegodišnjeg teritorijalnog spora na moru i kopnu međunarodnoj arbitraži. ${ }^{54}$ Sukladno članku l. Arbitražnog sporazuma početkom 2012. stranke su uspostavile peteročlani Arbitražni sud. Sporazumnim dogovorom stranke su za predsjednika Arbitražnog suda imenovale Gilberta Guillaumea iz Francuske, dok su za njegove članove imenovale Vaughna Lowea iz Ujedinjenoga Kraljevstva i Bruna Simmu iz Njemačke. Uz njih, Hrvatska je za člana Arbitražnog suda imenovala Budislava Vukasa iz Hrvatske, dok je Slovenija imenovala Jerneja Sekoleca iz Slovenije. Nakon prvog proceduralnog sastanka održanog 13. travnja 2012. uslijedila su tri kruga razmjene pisanih podnesaka između stranaka te je zatim od 2. do 13. lipnja 2014. održana i usmena rasprava pred Arbitražnim sudom. Nakon usmene rasprave Arbitražni sud započeo je s razmatranjem spora te se očekivalo da će konačna presuda u pogledu hrvatsko-slovenskog razgraničenja na kopnu i moru biti donesena u drugoj polovici 2015.

Međutim, 22. srpnja 2015. mediji, prvo Kurir i Newsweek Srbija u Srbiji, a zatim i Večernji list u Hrvatskoj, objavili su transkripte i tonske zapise dvaju telefonskih razgovora između Jerneja Sekoleca, člana Arbitražnog suda kojeg je imenovala Slovenija, te Simone Drenik, zastupnice Slovenije pred Arbitražnim sudom. ${ }^{55}$ Razgovori su se dogodili 15. studenog 2014. i 11. siječnja 2015., nakon što je završena rasprava, za vrijeme razmatranja Arbitražnog suda. Zapisi su otkrili da je Sekolec zastupnici Slovenije prenosio povjerljive informacije o razmatranju Tribunala i vjerojatnom ishodu arbitraže. ${ }^{56}$ Nadalje, zapisi su također otkrili

54 Za tekst Arbitražnog sporazuma vidi supra u bilj. 4.

55 Za transkripte dijela njihovih razgovora, prevedenih sa slovenskog na engleski jezik, vidi Excerpts from Recordings of Conversation Between Dr. Jernej Sekolec, Member of the Arbitral Tribunal, and Ms. Simona Drenik, Agent of the Republic of Slovenia, Ministarstvo vanjskih i europskih poslova Republike Hrvatske, 2015., http://www.mvep.hr/file s/ file/dokumenti/arbitraza/hr/150820-excerpts-from-recordings-between-dr-sekolecand-mr-drenik-14082015.pdf (1. srpnja 2019.).

56 Izvadak iz transkripta br. 1 :

"Jernej Sekolec: About the division of the Bay, a bigger part, a smaller part, we do not yet have a solution there. At one point, it was mentioned $1 / 4$ to $3 / 4$, but then 
raspravu o tome kako utjecati na druge članove Arbitražnog suda da presude u slovensku korist. ${ }^{57}$ Naposljetku, zapisi upućuju da je Sekolec primio dokumente od Drenik kako bi ih mogao koristiti kao svoje vlastite bilješke prilikom rasprave s drugim arbitrima..$^{58}$

\subsection{Bitna povreda Arbitražnog sporazuma}

Dan nakon objave zapisa, 23. srpnja 2015., Sekolec je podnio ostavku na svoju dužnost člana Arbitražnog suda, a ostavku je dala i Drenik na svoju dužnost

the President (Judge Gilbert Guillaume, President of the Arbitral Tribunal) on more occasions mentioned 2/3, $1 / 3$.

Simona Drenik: Yes.

Jernej Sekolec: Then, the line which would delimit the territorial sea would run from that point on the base line...

Simona Drenik: Yes.

Jernej Sekolec: ...of the Bay, where that line... In the worst example, it should not go below 1/3." Ibid., str. 1.

57 Izvadak iz transkripta br. 2.:

"Simona Drenik: How about, I am thinking, what if one day you got together with Bruno (Judge Bruno Simma, Member of the Arbitral Tribunal)? With Simma.

Jernej Sekolec: Listen, I agreed to meet with Bruno for dinner at his home, in any case.

Simona Drenik: Aha, great! And, you know, you give him one or two (murmur), say, OK, you know 'I looked at this, so you know, I think...' Not that you would give him 500 arguments. But you say 'I think, look at this...' He is not just anybody. Maybe he will then present it, but if you present it, he will look at it, Guillaume (Judge Gilbert Guillaume, President of the Arbitral Tribunal) I mean. But if Simma says 'Oh, it seems to me, we could look at this again'. " Ibid., str. 12.

58 Izvadak iz transkripta br. 1.:

"Simona Drenik: You know, I could prepare that for you. But, one thing is that it would be good for all those documents that they are sent so that you brought along your computer.

Jernej Sekolec: Yes. I have a file.

Simona Drenik: And then we. And then on your computer we save a file, and just transfer the documents, you know, the text. That is just so that afterwards you are recorded as the author of the file.

Jernej Sekolec: I understand, I understand, yes, yes.

Simona Drenik: If not, then it is nobody, or afterwards, someone there could find out that I am the author of the file. If I just opened the file with the key like on my computer, and transfer it to you into a new file, for each effectivité, we open a new one on your computer and save it, that is the best way, it would be good to do it that way. Jernej Sekolec: Yes, alright. (...)" Ibid., str. 7 - 8 . 
zastupnice Slovenije pred Arbitražnim sudom. S druge strane, Hrvatski sabor na svojoj izvanrednoj sjednici 29. srpnja 2015. jednoglasno je donio Zaključak o obvezi Vlade Republike Hrvatske na pokretanje postupka za prestanak Sporazuma o arbitraži između Vlade Republike Hrvatske i Vlade Republike Slovenije zbog bitne povrede Sporazuma od strane Republike Slovenije. ${ }^{59}$ Sukladno tome 30. srpnja 2015. Ministarstvo vanjskih i europskih poslova Republike Hrvatske uputilo je diplomatsku notu Sloveniji kojom ju je obavijestilo o hrvatskoj namjeri da pokrene postupak za prestanak Arbitražnog sporazuma zbog toga što je Slovenija bila uključena $u$ jednu ili više bitnih povreda Arbitražnog ugovora. ${ }^{60}$ Hrvatska je time i formalno pokrenula postupak za utvrđivanje prestanka međunarodnog ugovora zbog njegove bitne povrede koji je predviđen Bečkom konvencijom (članci 65. - 68.) Osim toga, Slovenija je bila obaviještena da od datuma upućivanja diplomatske note Hrvatska prestaje s primjenom Arbitražnog sporazuma. ${ }^{61}$ Nedugo zatim, 3. kolovoza 2015., Ronny Abraham iz Francuske, član Arbitražnog suda kojeg je Slovenija imenovala umjesto Sekoleca, podnio je ostavku na svoju dužnost nakon samo tjedan dana. Unatoč tome Slovenija je 13. kolovoza 2015. obavijestila Arbitražni sud da je stavila prigovor na hrvatsku notifikaciju o raskidu Arbitražnog sporazuma. ${ }^{62}$ Bilo je očito da je između Hrvatske i Slovenije nastao novi spor o postojanju bitne povrede Arbitražnog sporazuma, a samim time i prava Hrvatske na jednostrani raskid Arbitražnog sporazuma. S obzirom na to da je Slovenija u propisanom roku stavila prigovor na hrvatsku notifikaciju, sukladno članku 65. stavku 3. Bečke konvencije obje stranke spora morale su tražiti rješenje s pomoću sredstava mirnog rješavanja sporova navedenih u članku 33. Povelje Ujedinjenih naroda. Do rješenja spora nije došlo tijekom predviđenog roka od dvanaest mjeseci od stavljanja prigovora, te je strankama ostala mogućnost da na temelju članka 66. Bečke konvencije i

59 Vidi Zaključak o obvezi Vlade Republike Hrvatske na pokretanje postupka za prestanak Sporazuma o arbitraži između Vlade Republike Hrvatske i Vlade Republike Slovenije potpisanog 4. studenog 2009., Narodne novine, br. 85/2015.

60 Hrvatska je tom prilikom u diplomatskoj noti izjavila da je Slovenija prekršila čl. 6. Arbitražnog sporazuma koji je predviđao povjerljivost postupka, kao i čl. 10. Arbitražnog sporazuma koji je obvezivao stranke da se "suzdrže od svakog postupka ili izjave koja bi mogla ugroziti rad Arbitražnog suda”. Prema mišljenju Hrvatske, te odredbe bile su "bitne za ostvarenje predmeta i svrhe Arbitražnog sporazuma" te stoga njihovo kršenje predstavlja bitnu povredu Arbitražnog sporazuma u smislu čl. 60., st. 3. Bečke konvencije. Za tekst diplomatske note vidi supra u bilj. 5. Ibid.

Vidi PCA Press Release, Slovenia demands continuation of arbitration proceedings - Arbitral Tribunal clarifies further procedural steps, Permanent Court of Arbitration, 19 August 2015, https://pcacases.co m/web/sendAttach/1403 (1. srpnja 2019.). 
pripadajućeg Priloga podnošenjem zahtjeva glavnom tajniku Ujedinjenih naroda pokrenu postupak mirenja pred ad hoc komisijom za mirenje. Premda su Hrvatska i Slovenija jednostranim zahtjevom mogle pokrenuti postupak mirenja, do toga nije došlo. Uzrok tome s jedne strane možemo potražiti u činjenici da je Slovenija smatrala da je jedino Arbitražni sud ovlašten odlučiti o hrvatskom zahtjevu za prestankom Arbitražnog sporazuma ${ }^{63}$ te se istodobno protivila bilo kojem drugom načinu mirnog rješavanja spora. S druge strane, uzimajući u obzir otvoreno protivljenje Slovenije i osjetljivi politički kontekst spora, jednostrano pokretanje postupka mirenja od strane Hrvatske, premda formalno moguće, imalo je malo smisla jer su preporuke komisije za mirenje neobvezujućeg karaktera te kao takve ne bi mogle obvezivati Hrvatsku i Sloveniju, odnosno ne bi dovele do rješenja spora u slučaju protivljenja jedne od stranaka spora. Pitanje je li Slovenija počinila bitnu povredu Arbitražnog sporazuma ostalo je tako i dalje otvoreno.

Unatoč tome nema dvojbe da prethodno opisana komunikacija između člana Arbitražnog suda kojeg je imenovala Slovenija te zastupnice Slovenije pred Arbitražnim sudom bez prisustva predstavnika Hrvatske predstavlja ex parte komunikaciju. ${ }^{64}$ Štoviše, nije teško zaključiti da je upravo takva ex parte komunikacija zabranjena. ${ }^{65}$ Članak 6., stavak 5. Arbitražnog sporazuma više je nego jasan - "postupak je povjerljiv". Osim toga, članak 10., stavak 1. Arbitražnog sporazuma zahtijeva da se "obje stranke uzdrže od bilo kakvog postupka ili izjave koji mogu intenzivirati spor ili ugroziti rad Arbitražnog suda”. Važno je pri tome napomenuti da je djelovanje Simone Drenik, koja je tada djelovala u svojstvu zastupnika Slovenije, po međunarodnom pravu pripisivo Sloveniji. ${ }^{66}$

63 Vidi Arbitration Between the Republic of Croatia and the Republic of Slovenia, PCA Case No. 2012-04, Partial Award, 30 June 2016, str. 24, para. 102.

64 Međunarodno udruženje odvjetničkih komora (IBA) definira ex parte komunikaciju kao "usmenu ili pismenu komunikaciju između zastupnika stranke te arbitra ili potencijalnog arbitra bez prisustva ili znanja protivne stranke ili stranaka”. Vidi International Bar Association, IBA Guidelines on Party Representation in International Arbitration, International Bar Association, London, 2013., str. 3.

65 Usp. Newman, L. W.; Zaslowsky, D., When Arbitrators Stray: Ex Parte Communications, New York Law Journal, 25 September 2015, http://nysbar.com/blogs/ ResolutionRoundtable/When\%20Arbitrators\%20Stray.pdf (1. srpnja 2019.).

66 Vidi Brownlie, op. cit. u bilj. 16, str. 446 - 454; Shaw, op. cit. u bilj. 22, str. 572; Difference Relating to Immunity from Legal Process of a Special Rapporteur of the Commission on Human Rights, Advisory Opinion, I.C.J. Reports, 1999., str. 87, para. 62. Čl. 4. Nacrta članaka o odgovornosti država za međunarodno protupravne čine tako propisuje: "1. The conduct of any State organ shall be considered an act of that State under international law, whether the organ exercises legislative, executive, judicial 
Drugim riječima, Slovenija je prekršila odredbe Arbitražnog sporazuma. Premda je nesporno da je Slovenija prekršila odredbe Arbitražnog sporazuma, ostaje i dalje otvoreno pitanje jesu li spomenuta kršenja ujedno i bitna povreda Arbitražnog sporazuma u smislu članka 60. Bečke konvencije.

Kako bismo odgovorili na to pitanje, potrebno je prvo pogledati u Bečku konvenciju, čije su stranke Hrvatska i Slovenija. Sukladno članku 60., stavku 3. Bečke konvencije postoje dva oblika bitne povrede međunarodnog ugovora a) odbacivanje ugovora te b) povreda odredbe bitne za ostvarenje predmeta ili svrhe ugovora. U konkretnom slučaju Slovenija nije odbacila ugovor, odnosno nije odbila izvršavati sve svoje ugovorne obveze, kao što je to primjerice napravila Južna Afrika u pogledu Mandata za Jugozapadnu Afriku. ${ }^{67}$ I dok je Južna Afrika dosljedno odbijala primjenjivati sve odredbe ugovora, odnosno odbacila je ugovor u cijelosti, Slovenija je prekršila neke od odredbi Arbitražnog sporazuma. Štoviše, nakon razotkrivanja ex parte komunikacije Slovenija je tvrdila da se Arbitražni sporazum nastavlja primjenjivati. ${ }^{68}$ Osim toga, Slovenija je također izričito priznala i svoje trajne obveze po Arbitražnom sporazumu ${ }^{69}$ Premda Slovenija nije odbacila Arbitražni sporazum u smislu članka 60., stavka 3., točke a) Bečke konvencije, kršenja Arbitražnog sporazuma od strane Slovenije još uvijek mogu predstavljati bitnu povredu po članku 60., stavku 3., točki b) Bečke konvencije.

\subsubsection{Predmet i svrha Arbitražnog sporazuma}

S obzirom na to da članak 60., stavak 3., točka b) predviđa da bitnu povredu ugovora predstavlja povreda odredbe bitne za ostvarenje predmeta ili svrhe ugovora, potrebno je prvo utvrditi predmet i svrhu Arbitražnog sporazuma. Korisna

or any other functions, whatever position it holds in the organization of the State, and whatever its character as an organ of the central Government or of a territorial unit of the State. 2. An organ includes any person or entity which has that status in accordance with the internal law of the State." Za tekst Nacrta vidi Report of the International Law Commission on the work of its fifty-third session, 23 April - 1 June, 2 July - 10 August 2001, General Assembly Official Records, Fifty-sixth session, Supplement No. 10 (A/56/10) (2001).

67 Vidi Legal Consequences for States of the Continued Presence of South Africa in Namibia (South West Africa) notwithstanding Security Council Resolution 276 (1970), Advisory Opinion, I.C.J. Reports, 1971., str. 47, para. 94.

Vidi Arbitration Between the Republic of Croatia and the Republic of Slovenia, PCA Case No. 2012-04, Partial Award, 30 June 2016, str. 53, para. 214.

Ibid. 
smjernica za utvrđivanje predmeta i svrhe Arbitražnog sporazuma stajalište je Međunarodnog suda u parnici o Arbitražnoj presudi od 31. srpnja 1989. između Gvineje Bisao i Senegala. Međunarodni sud tom je prilikom ustvrdio da je arbitražni sporazum "sporazum koji ima vrlo specifični predmet i svrhu: povjeriti arbitražnom sudu zadaću rješavanja spora u skladu s uvjetima dogovorenima između stranaka, koje u sporazumu definiraju jurisdikciju suda i utvrđuju njezine granice" ${ }^{70}$ Primjereno tome, predmet i svrha Arbitražnog sporazuma je, prema njegovu članku 3., stavku 1. i članku 4., rješavanje teritorijalnog spora između Hrvatske i Slovenije primjenjujući pravila i načela međunarodnog prava (prilikom utvrđivanja morske i kopnene granice), odnosno primjenjujući međunarodno pravo, pravičnost i načelo dobrosusjedskih odnosa u svrhu postizanja poštenog i pravednog rezultata (prilikom utvrđivanja veze Slovenije prema otvorenom moru i režima za uporabu relevantnih morskih voda). Osim toga, predmet i svrha Arbitražnog sporazuma bio je, prema njegovu članku 9., nastavak pregovora o pristupanju Hrvatske Europskoj uniji.

\subsubsection{Povreda odredbe bitne za ostvarenje predmeta i svrhe Arbitražnog sporazuma}

Budući da je jedan od predmeta i svrha Arbitražnog sporazuma već bio ostvaren - nastavak pregovora o pristupanju Hrvatske Europskoj uniji, ostaje utvrditi jesu li kršenja Arbitražnog sporazuma od strane Slovenije onemogućila ostvarenje preostalog predmeta i svrhe Arbitražnog sporazuma. Neosporna je činjenica da kršenje članka 6., stavka 5. Arbitražnog sporazuma, odnosno odredbe o povjerljivosti postupka, predstavlja povredu temeljnih načela arbitražnog postupka, uključujući načela pravičnog postupka (due process), proceduralne pravičnosti (procedural fairness), nepristranosti i neovisnosti. Štoviše, upravo su spomenuta načela bitna za ostvarenje predmeta i svrhe arbitražnog ugovora s obzirom na to da imaju ključnu ulogu u donošenju poštene i pravedne presude $\mathrm{u}$ arbitražnom postupku. ${ }^{71}$

Naime, pojam pravičnog postupka u međunarodnoj arbitraži proizlazi iz općih načela prava te je kao takav kamen temeljac međunarodnog arbitražnog postupka. ${ }^{72}$ Osim toga, pravičan postupak smatra se jezgrom ili temeljem svih

70 Arbitral Award of 31 July 1989 (Guinea-Bissau v. Senegal), Judgment, I.C.J. Reports, 1991., str. 70, para. 49.

71 Vidi Ilic, M., Croatia v. Slovenia: The Defiled Proceedings, Arbitration Law Review, sv. 9, 2017., str. $360-371$.

72 Vidi također: Kotuby, C. T., General Principles of Law, International Due Process, and the Modern Role of Private International Law, Duke Journal of Comparative \& 
drugih postupovnih pravila. ${ }^{73}$ Premda ne postoji općeprihvaćena definicija pravičnog postupka, postoji opće slaganje oko njegovih ključnih konstitutivnih elemenata. Primjereno tome, pojam pravičnog postupka među ostalim obuhvaća pravo na obavijest (right to notice), pravo na saslušanje (right to be heard), pravo na procesnu ravnopravnost (equality of arms - 'jednakost oružja' ${ }^{74}$, te pravo na neovisni i nepristrani sud (independence and impartiality). ${ }^{75}$ Upravo stoga pravičan postupak u međunarodnoj arbitraži može se opisati kao štit koji štiti bitna postupovna prava stranaka u arbitražnom postupku.

Nadalje, proceduralna pravičnost, jedno od načela koje proizlazi iz pravičnog postupka, također je među najvažnijim načelima međunarodnog arbitražnog postupka. Prema istraživanju provedenom među odvjetnicima i njihovim klijentima u međunarodnim arbitražama velika većina sudionika ankete rangirala je pošten i pravedan rezultat, koji je usko povezan s proceduralnom pravičnošću, odnosno temelji se na njoj, kao najvažniji atribut arbitražnog postupka. ${ }^{76}$ Štoviše, pošten i pravedan rezultat bio je gotovo dvostruko važniji od sljedećeg rangiranog atributa. ${ }^{77}$

Naposljetku, jedno od fundamentalnih načela međunarodne arbitraže je neovisnost i nepristranost arbitara, drugim riječima, svaki arbitar mora biti i ostati neovisan i nepristran. Iako su "neovisnost" i "nepristranost" dva različita pojma, ona su snažno povezana te ih stoga treba promatrati kao dvije strane iste

International Law, sv. 23, 2013., str. 426; Reed, L., Ab(use) of due process: sword vs shield, Arbitration International, sv. 33, 2017., str. 365.

73 Kurkela, M.; Turunen, S., Due Process in International Commercial Arbitration, Oxford University Press, Oxford, 2010., str. 4.

74 Načelo jednakosti oružja prvi je razvio Europski sud za ljudska prava (ECHR). Prema ECHR-u načelo jednakosti oružja podrazumijeva da svaka stranka mora imati razumnu mogućnost da izloži svoj slučaj, uključujući i svoje dokaze, pod uvjetima koji je ne stavljaju u znatno nepovoljniji položaj vis-à-vis protivne stranke. Vidi Dombo Beheer B.V. v. The Netherlands, App. no. 14448/88, ECHR, Judgment, 27 October 1993, str. 14, para. 33.

75 Vidi također: Fortese, F.; Hemmi, L., Procedural Fairness and Efficiency in International Arbitration, Groningen Journal of International Law, sv. 31, 2015., str. 111; Kurkela, Turunen, op. cit. u bilj. 73, str. 2; Reed, op. cit. u bilj. 72, str. 366; Cairns, D. J. A., Oral Advocacy and Time Control in International Arbitration, u: Berg, A. J. van den (ur.), Arbitration Advocacy in Changing Times, Kluwer Law International, Alphen aan den Rijn, 2011., str. 187.

76 Naimark, R. W.; Keer, S. E., International Private Commercial Arbitration: Expectations and Perceptions of Attorneys and Business People, International Business Lawyer, sv. 30, br. 5, 2002., str. $203-205$.

77 Ibid. 
kovanice. ${ }^{78}$ Neovisnost se odnosi na odnos između arbitra i jedne od stranaka. Općenito se smatra da je neovisnost objektivniji pojam jer nema nikakve veze sa stanjem uma arbitra. ${ }^{79} \mathrm{~S}$ druge strane, nepristranost se odnosi na pristranost arbitra prema jednoj od stranaka. Upravo stoga se nepristranost smatra subjektivnijim i apstraktnijim konceptom od neovisnosti jer uključuje ponajprije stanje uma arbitra. ${ }^{80} \mathrm{U}$ svakom slučaju, oba su pojma conditio sine qua non za vođenje arbitražnog postupka te donošenje poštene i pravedne presude.

Da spomenuta načela imaju ključnu ulogu u međunarodnom arbitražnom postupku te donošenju poštene i pravedne presude, svjedoči i činjenica da su implementirana u pravilima vodećih međunarodnih arbitražnih institucija ${ }^{81}$, kao i u tzv. soft law pravilima odvjetničkih komora. ${ }^{82}$ Primjereno tome, ona se nalaze i u Fakultativnim pravilima Stalnog arbitražnog suda u sporovima izme-

78 Vidi također: Jenkins, J.; Stebbings, S., International Construction Arbitration Law, Kluwer Law International, Alphen aan den Rijn, 2006., str. 151.

79 Redfern, A.; Hunter, M., Law and Practice of International Commercial Arbitration, Sweet \& Maxwell, London, 2004., para. 4- 55.

80

Ibid.

81 Vidi npr. čl. 6., st. 7. i čl. 17., st. 1. Arbitražnih pravila Komisije Ujedinjenih naroda za međunarodno trgovačko pravo, za tekst Pravila vidi United Nations Commission on International Trade Law, UNICTRAL Arbitration Rules, UNCITRAL Rules on Transparency in Treaty-based Investor-State Arbitration, United Nations, New York, 2014.; čl. 11., st. 1. i čl. 22., st. 4. Arbitražnih pravila Međunarodne trgovačke komore, za tekst Pravila vidi International Chamber of Commerce, Arbitration Rules, Mediation Rules, International Chamber of Commerce, Paris, 2017.; čl. 13., st. 1. i čl. 20., st. 1. Međunarodnih arbitražnih pravila Međunarodnog centra za rješavanje sporova, za tekst Pravila vidi International Centre for Dispute Resolution, International Dispute Resolution Procedures, 2016., https://www.icdr.org/sites/default/files/document_repository/ICDR_Rules.pdf (1. srpnja 2019.); pravilo 6., st. 2. Arbitražnih pravila Međunarodnog centra za rješavanje investicijskih sporova, za tekst Pravila vidi International Centre for Settlement of Investment Disputes, ICSID Convention, Regulations and Rules, April 2006, https://icsid.worldbank.org/en/Documents/ resources/2006\%20CRR_English-final.pdf (1. srpnja 2019.); čl. 5., st. 4., čl. 14., st. 4., čl. 14., st. 5. Arbitražnih pravila Londonskog suda za međunarodnu arbitražu, za tekst Pravila vidi London Court of International Arbitration, LCIA Arbitration Rules, 1 October 2014, http://www. lcia.org/Dispute_Resolution_Services/lcia-arbitration-rules-2014.aspx\#Article 13 (1. srpnja 2019.).

82 Vidi npr. smjernice 1. i 27. IBA-inih Smjernica o zastupanju stranaka u međunarodnim arbitražama, za tekst Smjernica vidi supra u bilj. 66. Vidi i pravilo 3.1. IBAinih Etičkih pravila za međunarodne arbitre, za tekst Pravila vidi International Bar Association, IBA Rules of Ethics for International Arbitrators 1987, https://www. translex.org/701100/_iba-rules-of-ethics-for-international-arbitrators-1987/ (1. srpnja 2019.). 
đu dviju država prema kojima se vodio arbitražni postupak između Hrvatske i Slovenije. ${ }^{83}$ Tako Fakultativna pravila jasno ističu zahtjev za neovisnošću i nepristranošću arbitara ${ }^{84}$, kao i zahtjev za proceduralnom pravičnošću, odnosno procesnom jednakošću stranaka te potpunim ostvarenjem prava na saslušanje tijekom cijelog postupka. ${ }^{85}$ Osim toga, odjeljak 3. 4. Uvjeta imenovanja navodi da su "članovi Arbitražnog suda nepristrani i neovisni od stranaka te da će tako i dalje ostati", dok odjeljak 9. 1. Uvjeta imenovanja jasno predviđa da se "stranke neće upuštati u bilo koju usmenu ili pismenu ex parte komunikaciju s bilo kojim članom Arbitražnog suda u pogledu predmeta arbitraže ili bilo kojeg proceduralnog pitanja povezanog s postupkom". ${ }^{86}$ Naposljetku, zanimljivo je primijetiti da je i sam Arbitražni sud također prepoznao važnost, ali i dužnost zaštite procesnih prava obiju stranaka u sporu. ${ }^{87}$ Tako, prema Arbitražnom sudu, proceduralna pravičnost uključuje pravo na nepristranog i neovisnog suca, što je za Sud od najveće važnosti u arbitražnom postupku. ${ }^{88}$

Unatoč svemu navedenome Slovenija je ex parte komunikacijom u arbitražnom postupku svjesno i mala fide povrijedila temeljna načela arbitražnog postupka, koja su pak nužna za ostvarenje predmeta i svrhe Arbitražnog sporazuma. Uz to, ex parte komunikacija u potpunosti je nekompatibilna is "načelom dobrosusjedskih odnosa”, koje je također trebalo poslužiti za rješavanje graničnog spora između Hrvatske i Slovenije. Upravo stoga, služeći se riječima Međunarodnog suda u slučaju Nikaragva, možemo zaključiti da su aktivnosti Slovenije "podrovale cijeli duh" Arbitražnog sporazuma usmjerenog na rješavanje teritorijalnog spora između stranaka u skladu s pravilima i načelima međunarodnog prava, pravičnošću i načelom dobrosusjedskih odnosa kako bi se postigao pošten i pravedan rezultat. Naime, teško je razumjeti da tako teške povrede temeljnih načela arbitražnog postupka ne predstavljaju čin koji je sračunat da bi se porazio predmet i svrha Arbitražnog sporazuma s obzirom na to da su ta načela esencijalna za integritet

83 Za tekst Fakultativnih pravila Stalnog arbitražnog suda u sporovima između dviju država vidi https://pca-cpa.org/en/services/arbitration-services/pca-arbitrationrules-2012/ (1. srpnja 2019.).

Vidi čl. 6., st. 4. i članke 9. - 12. Fakultativnih pravila.

Čl. 15., st. 1. Fakultativnih pravila jasno određuje da "arbitražni sud može voditi arbitražu na način koji smatra prikladnim, pod uvjetom da se prema strankama postupa jednako i da u svakoj fazi postupka svaka stranka ima punu mogućnost da iznese svoj slučaj”.

Ibid., str. 56, para. 227. 
arbitražnog postupka te donošenje poštene i pravedne presude. Primjereno tome, djelovanje Slovenije, odnosno ex parte komunikacija predstavlja bitnu povredu Arbitražnog sporazuma u smislu članka 60., stavka 3., točke b) Bečke konvencije jer je porazila predmet i svrhu Arbitražnog sporazuma. ${ }^{89} \mathrm{U}$ protivnom, zanemarivanje teških povreda temeljnih načela arbitražnog postupka i umanjivanje njihove ključne uloge u donošenju poštene i pravedne presude dovelo bi u pitanje smisao postojanja arbitraže kao sredstva za mirno rješavanje sporova.

\subsubsection{Djelomična presuda Arbitražnog suda}

Premda Hrvatska više nije sudjelovala u arbitražnom postupku nakon svojega povlačenja iz njega, 25. rujna 2015. predsjednik Arbitražnog suda Guillaume imenovao je nove članove Arbitražnog suda, Nicolasa Michela iz Švicarske umjesto Vukasa te Rolfa Einara Fifea iz Norveške umjesto Abrahama. Tako rekonstituiran Arbitražni sud nastavio je postupak, ali bez sudjelovanja Hrvatske, te je 30. lipnja 2016. donio djelomičnu presudu (Partial Award) glede izražene hrvatske namjere da raskine Arbitražni sporazum te glede pravnih posljedica događaja koji su doveli do takve odluke Hrvatske. U presudi je Arbitražni sud utvrdio da, uzimajući u obzir poduzete korektivne mjere, povrede Arbitražnog sporazuma od strane Slovenije nisu onemogućile nastavak arbitražnog postupka te stoga nisu povrijedile predmet i svrhu Arbitražnog sporazuma. ${ }^{90}$ Primjereno tome, Arbitražni sud presudio je da Hrvatska nije bila ovlaštena raskinuti Arbitražni sporazum na temelju članka 60., stavka l. Bečke konvencije te da Arbitražni sporazum ostaje na snazi. ${ }^{91}$

Očito je da Arbitražni sud prilikom donošenja presude nije uzeo u obzir teške povrede temeljnih načela arbitražnog postupka te je umanjio njihovu ključnu ulogu u donošenju poštene i pravedne presude. S druge strane, Arbitražni sud je mislio da će korektivnim mjerama - u prvom redu imenovanjem novih članova Arbitražnog suda umjesto Vukasa, koji je podnio ostavku, te Abrahama, koji je također podnio ostavku zamijenivši prethodno kompromitiranog Sekoleca - uspostaviti procesnu ravnotežu između stranaka koja je nužna za vođenje pravičnog postupka te ostvarenje predmeta i svrhe Arbitražnog sporazuma. Štoviše, Arbitražni sud u potpunosti je zanemario činjenicu da je ex parte komunikacija omogućila Sloveniji da preko arbitra Sekoleca, koji je djelovao de facto

89 Vidi također: Ilic, op. cit. u bilj. 71, str. $373-374$.

90 Arbitration Between the Republic of Croatia and the Republic of Slovenia, PCA Case No. 2012-04, Partial Award, 30 June 2016, str. 55, para. 225.

91 Ibid. 
kao njezin zastupnik, izravno utječe na formiranje stajališta preostalih članova Arbitražnog suda u pogledu konačnog rješenja spora na štetu Hrvatske. ${ }^{92}$ Osim toga, Arbitražni sud zanemario je i činjenicu da je zahvaljujući "neformalnom kanalu komuniciranja s Arbitražnim sudom” Slovenija dobila pristup povjerljivim informacijama glede razmatranja Arbitražnog suda, koja su uključivala i poglede arbitara na određene činjenice i argumente $\mathrm{u}$ sporu, te da je na taj način ostvarila stratešku procesnu prednost nad Hrvatskom. U takvim okolnostima, čak i uz poduzete korektivne mjere, ostvarenje predmeta i svrhe Arbitražnog sporazuma više nije bilo moguće. Upravo je stoga pogrešno stajalište Arbitražnog suda prema kojem kršenja Arbitražnog sporazuma, odnosno povrede temeljnih načela arbitražnog postupka od strane Slovenije, nisu porazila predmet i svrhu Arbitražnog sporazuma.

\section{ZAKLJUČAK}

Premda je načelo pacta sunt servanda jedno od najstarijih općih načela prava te ujedno i kamen temeljac prava međunarodnih ugovora, u praksi često dolazi do kršenja međunarodnih ugovora. Upravo je stoga međunarodno običajno pravo priznalo oštećenoj stranci pravo na jednostrani raskid ugovora kao odgovor na njegovo kršenje. Spomenuto pravo na jednostrani raskid ugovora kodificirano je zatim i Bečkom konvencijom o pravu međunarodnih ugovora iz 1969., pri čemu je dijelom došlo i do progresivnog razvoja međunarodnog prava u tom pitanju. Naime, budući da svaka povreda ugovora nije iste prirode, člankom 60., stavkom 1. Bečke konvencije propisano je da jedino bitna povreda međunarodnog ugovora ovlašćuje oštećenu stranku da se pozove na povredu kao na uzrok prestanka ugovora. Osim toga, člankom 60., stavkom 3. Bečke konvencije definiran je i koncept bitne povrede s obzirom na to da je riječ o ključnom uvjetu za stjecanje prava na jednostrani raskid ugovora.

Upravo do takve bitne povrede međunarodnog ugovora došlo je za vrijeme arbitraže između Hrvatske i Slovenije. Ex parte komunikacija između Jerneja Sekoleca, člana Arbitražnog suda kojeg je imenovala Slovenija, te Simone Drenik, zastupnice Slovenije pred Arbitražnim sudom, neosporno je prekršila članak 6., stavak 5. Arbitražnog sporazuma između Hrvatske i Slovenije, koji je propisivao da je postupak povjerljiv. Međutim, kršenje spomenutog članka ujedno je i povreda temeljnih načela arbitražnog postupka, uključujući načela pravičnog postupka, proceduralne pravičnosti, nepristranosti i neovisnosti. S obzirom na to da su spomenuta načela ključna za ostvarenje predmeta i svrhe

92 Usp. Ilic, op. cit. u bilj. 71, str. 376. 
arbitražnog sporazuma - rješavanje teritorijalnog spora između Hrvatske i Slovenije primjenjujući pravila i načela međunarodnog prava, pravičnost i načelo dobrosusjedskih odnosa u svrhu postizanja poštenog i pravednog rezultata - možemo zaključiti da ex parte komunikacija, odnosno djelovanje Slovenije predstavlja bitnu povredu Arbitražnog sporazuma u smislu članka 60., stavka 3., točke b) Bečke konvencije.

\section{LITERATURA}

\section{Knjige i članci}

Brierly, J. L, The Law of Nations, Oxford University Press, New York, Oxford, 1960. Briggs, H. W., Procedures for Establishing the Invalidity or Termination of Treaties under the International Law Commission's 1966 Draft Articles on the Law of Treaties, American Journal of International Law, sv. 61, 1967., str. 976 - 989

Brownlie, I., Principles of Public International Law, Oxford University Press, Oxford, 2008.

Cairns, D. J. A., Oral Advocacy and Time Control in International Arbitration, u: Berg, A. J. van den (ur.), Arbitration Advocacy in Changing Times, Kluwer Law International, Alphen aan den Rijn, 2011., str. 181 - 201

Crnić-Grotić, V., Pravo međunarodnih ugovora, Pravni fakultet Sveučilišta u Rijeci, Rijeka, 2002.

Fitzmaurice, M., Material Breach of Treaty: Some Legal Issues, Austrian Review of International and European Law, sv. 6, 2001., str. 3 - 44

Fortese, F.; Hemmi, L., Procedural Fairness and Efficiency in International Arbitration, Groningen Journal of International Law, sv. 31, 2015., str. 110 - 124

Giegerich, T., Article 60. Termination or Suspension of the Operation of a Treaty as a Consequence of its Breach, u: Dörr, O.; Schmalenbach, K. (ur.), Vienna Convention on the Law of Treaties: A Commentary, Springer, Berlin, 2018., str. 1095 - 1125

Gomaa, M. M., Suspension or Termination of Treaties on Grounds of Breach, Martinus Nijhoff, The Hague - Boston, 1996.

Greig, D. W., Reciprocity, Proportionality and the Law of Treaties, Virginia Journal of International Law, sv. 34, 1995., str. 295 - 403

Ilic, M., Croatia v. Slovenia: The Defiled Proceedings, Arbitration Law Review, sv. 9, 2017., str. $347-383$

Jenkins, J.; Stebbings, S., International Construction Arbitration Law, Kluwer Law International, Alphen aan den Rijn, 2006. 
Kirgis Jr., F. L., Some Lingering Questions about Article 60 of the Vienna Convention on the Law of Treaties, Cornell International Law Journal, sv. 22, 1989., str. 549 - 573

Kotuby, C. T., General Principles of Law, International Due Process, and the Modern Role of Private International Law, Duke Journal of Comparative \& International Law, sv. 23, 2013., str. 411 - 443

Krieger, H., Annex to Article 66., u: Dörr, O.; Schmalenbach, K. (ur.), Vienna Convention on the Law of Treaties: A Commentary, Springer, Berlin, 2018., str. $1243-1252$

Kurkela, M.; Turunen, S., Due Process in International Commercial Arbitration, Oxford University Press, Oxford, 2010.

Lapaš, D., Sankcija u međunarodnom pravu, Pravni fakultet Sveučilišta u Zagrebu, Zagreb, 2004.

Lapaš, D.; Šošić, T. M. (ur.), Međunarodno javno pravo: izbor dokumenata, Pravni fakultet u Zagrebu, Zagreb, 2005.

McNair, A., Law of Treaties, Clarendon Press, Oxford, 1961.

Naimark, R. W.; Keer, S. E., International Private Commercial Arbitration: Expectations and Perceptions of Attorneys and Business People, International Business Lawyer, sv. 30, br. 5, 2002., str. 203 - 209

Newman, L. W.; Zaslowsky, D., When Arbitrators Stray: Ex Parte Communications, New York Law Journal, 25 September 2015, http://nysbar.com/blogs/ResolutionRoundtable/When\%20Arbit rators\%20Stray.pdf

Oppenheim, L. F., International Law: A Treatise, sv. I, Longmans, Green and Co., London - New York - Bombay - Calcutta, 1912.

Prost, M., Article 65: Procedure to Be Followed with Respect to Invalidity, Termination, Withdrawal from or Suspension of the Operation of a Treaty, u: Corten, O.; Klein, P. (ur.), The Vienna Conventions on the Law of Treaties: A Commentary, sv. II, Oxford University Press, Oxford, 2011., str. 1483 - 1508

Reed, L., Ab(use) of due process: sword vs shield, Arbitration International, sv. 33, 2017., str. $361-377$

Redfern, A.; Hunter, M., Law and Practice of International Commercial Arbitration, Sweet \& Maxwell, London, 2004.

Reisman, W. M., Procedures for Controlling Unilateral Treaty Terminations, American Journal of International Law, sv. 63, 1969., str. 544 - 547

Reuter, P., Introduction to the Law of Treaties, Pinter Publishers, London, 1989.

Rosenne, S., Settlement of Treaty Disputes under the Vienna Convention of 1969, Zeitschrift für ausländisches öffentliches Recht und Völkerrecht, sv. 31, 1971., str. $1-62$ 
Rosenne, S., Breach of Treaty, Cambridge University Press, Cambridge, 1985.

Seršić, M., Međunarodnopravna odgovornost države, Pravni fakultet Sveučilišta u Zagrebu, Zagreb, 2007.

Shaw, M. N., International Law, Cambridge University Press, Cambridge, 2014.

Sinha, B. P., Unilateral Denunciation of Treaty Because of Prior Violations of Obligations by Other Party, Martinus Nijhoff, The Hague, 1966.

Simma, B., Reflections on Article 60 of the Vienna Convention on the Law of Treaties and its Background in General International Law, Österreichische Zeitschrift für öffentliches Recht, sv. 20, 1970., str. 5 - 83

Simma, B.; Tams, C. J., Article 60: Termination or Suspension of the Operation of a Treaty as a Consequence of its Breach, u: Corten, O.; Klein, P. (ur.), The Vienna Conventions on the Law of Treaties: A Commentary, sv. II, Oxford University Press, Oxford, 2011., str. 1351 - 1378

Simma, B.; Tams, C. J., Reacting against treaty breaches, u: Hollis, D. B. (ur.), The Oxford Guide to Treaties, Oxford University Press, Oxford, 2012., str. 576-604

Sinclair, I. M., The Vienna Convention on the Law of Treaties, Manchester University Press, Manchester, 1973.

Villiger, M. E., Commentary on the 1969 Vienna Convention on the Law of Treaties, Martinus Nijhoff Publishers, Leiden - Boston, 2009.

Whitton, J. B., The Sanctity of Treaties (Pacta Sunt Servanda), International Conciliation, sv. 16, 1934./1935., str. 395 - 430

\section{Sudska praksa}

Appeal Relating to the Jurisdiction of the ICAO Council (India v. Pakistan), Judgment, I.C.J. Reports, 1972., str. 46

Application of the Interim Accord of 13 September 1995 (the former Yugoslav Republic of Macedonia v. Greece), Judgment, I.C.J. Reports, 2011., str. 644

Arbitral Award of 31 July 1989 (Guinea-Bissau v. Senegal), Judgment, I.C.J. Reports, 1991., str. 53

Arbitration Between the Republic of Croatia and the Republic of Slovenia, PCA Case No. 2012-04, Partial Award, 30 June 2016.

Case concerning the Air Service Agreement of 27 March 1946 between the United States of America and France, Decision of 9 December 1978, UNRIAA, sv. 18, str. 417

Case concerning the difference between New Zealand and France concerning the interpretation or application of two agreements, concluded on 9 July 1986 between the two 
States and which related to the problems arising from the Rainbow Warrior Affair (France v. New Zealand), Decision of 30 April 1990, UNRIAA, sv. XX, str. 215 Difference Relating to Immunity from Legal Process of a Special Rapporteur of the Commission on Human Rights, Advisory Opinion, I.C.J. Reports, 1999., str. 62

Diversion of water from the Meuse (Netherland v. Belgium), Judgment, P.C.I.J. 1937 (Series A/B), No. 70, str. 3

Dombo Beheer B.V. v. The Netherlands, App. no. 14448/88, ECHR, Judgment, 27 October 1993.

Gabčikovo-Nagymaros Project (Hungary v. Slovakia), Judgment, I.C.J. Reports, 1997., str. 7

Legal Consequences for States of the Continued Presence of South Africa in Namibia (South West Africa) notwithstanding Security Council Resolution 276 (1970), Advisory Opinion, I.C.J. Reports, 1971., str. 16

Military and Paramilitary Activities in and against Nicaragua (Nicaragua v. United States of America), Merits, Judgment, I.C.J. Reports, 1986., str. 14

Tacna-Arica question (Chile v. Peru), Opinion and Award of 4 March 1925, UNRIAA, sv. II, str. 921

\section{Ostali izvori}

Bečka konvencija o pravu međunarodnih ugovora iz 1969., United Nations Treaty Series, sv. 1155, 1980., str. 331

Excerpts from Recordings of Conversation Between Dr. Jernej Sekolec, Member of the Arbitral Tribunal, and Ms. Simona Drenik, Agent of the Republic of Slovenia, Ministarstvo vanjskih i europskih poslova Republike Hrvatske, 2015., http://www. mvep.hr/files/file/dokumenti/arbitraza/hr/150820-excerpts-from-recordingsbetween-dr-sekolec-and-mr-drenik-14082015.pdf

Fakultativna pravila Stalnog arbitražnog suda u sporovima između dviju država, https://pca-cpa.org/en/services/arbitration-services/pca-arbitration-rules-2012/

Harvardski nacrt konvencije o pravu međunarodnih ugovora iz 1935., American Journal of International Law, sv. 29 (Suppl.), 1935., str. 657

International Bar Association, IBA Guidelines on Party Representation in International Arbitration, International Bar Association, London, 2013.

International Bar Association, IBA Rules of Ethics for International Arbitrators 1987, https://www. trans-lex.org/701100/_iba-rules-of-ethics-for-international-arbitrators-1987/ 
International Centre for Dispute Resolution, International Dispute Resolution Procedures, 2016., https://www.icdr.org/sites/default/files/document_repository/ ICDR_Rules.pdf

International Centre for Settlement of Investment Disputes, ICSID Convention, Regulations and Rules, April 2006, https://icsid.worldbank.org/en/Documents/ resources/2006\%20CRR_English-final.pdf

International Chamber of Commerce, Arbitration Rules, Mediation Rules, International Chamber of Commerce, Paris, 2017.

London Court of International Arbitration, LCIA Arbitration Rules, 1 October 2014, http://www. lcia.org/Dispute_Resolution_Services/lcia-arbitration-rules-2014.aspx\#Article 13

Note verbale from the Ministry of Foreign and European Affairs of the Republic of Croatia to the Ministry of Foreign Affairs of the Republic of Slovenia, Note No. 3303/2015, 30 July 2015, http://www.mvep.hr/files/file/dokumenti/arbitraza/hr/150820-note-verbale-no-3303-2015-(to-the-republic-of-slovenia).pdf

PCA Press Release, Slovenia demands continuation of arbitration proceedings - Arbitral Tribunal clarifies further procedural steps, Permanent Court of Arbitration, 19 August 2015, https://pcacases.co m/web/sendAttach/1403

Povelja Ujedinjenih naroda, United Nations Treaty Series, sv. 1, 1945., str. XV Report of the International Law Commission on the work of its fifty-third session, 23 April - 1 June, 2 July - 10 August 2001, General Assembly Official Records, Fifty-sixth session, Supplement No. 10 (A/56/10) (2001)

Sporazum o arbitraži između Vlade Republike Hrvatske i Vlade Republike Slovenije, United Nations Treaty Series, sv. 2748, 2015., str. 3

UN Doc. A/CONF.39/11 Add. 1 .

United Nations Commission on International Trade Law, UNICTRAL Arbitration Rules, UNCITRAL Rules on Transparency in Treaty-based Investor-State Arbitration, United Nations, New York, 2014.

Yearbook of the International Law Commission, sv. II, 1957.

Yearbook of the International Law Commission, sv. II, 1963.

Yearbook of the International Law Commission, sv. II, 1966.

Zaključak o obvezi Vlade Republike Hrvatske na pokretanje postupka za prestanak Sporazuma o arbitraži između Vlade Republike Hrvatske i Vlade Republike Slovenije potpisanog 4. studenog 2009., Narodne novine, br. $85 / 2015$. 
Summary

Ljubo Runjić*

\section{MATERIAL BREACH OF A TREATY ON THE EXAMPLE OF THE ARBITRATION AGREEMENT BETWEEN CROATIA AND SLOVENIA}

This paper determines the existence of a material breach of the Arbitration Agreement between Croatia and Slovenia within the meaning of Article 60 of the Vienna Convention on the Law of Treaties of 1969, and thus the validity of Croatia's request to terminate the Arbitration Agreement. To be more specific, Article 60 of the Vienna Convention provides for the right to unilaterally terminate a treaty in the case of its material breach. Given that the existence of a material breach is a key condition for acquiring the right to unilaterally terminate a treaty, the notion of material breach is considered, with a particular emphasis on the criteria for material breach laid down in Article 60 of the Vienna Convention. On that basis, the paper analyzes whether Slovenia's actions, i.e. ex parte communication in the arbitration between Croatia and Slovenia represents a repudiation of a treaty or a violation of a provision of the Arbitration Agreement essential to the accomplishment of its object and purpose. Finally, the paper argues that Slovenia has materially breached the Arbitration Agreement within the meaning of Article 60 of the Vienna Convention.

Keywords: material breach, treaty, ex parte communication, Arbitration Agreement between Croatia and Slovenia

* Ljubo Runjić, Ph. D., Senior Lecturer, Polytechnic of Šibenik, Trg Andrije Hebranga 11, Šibenik; runjic@vus.hr;

ORCID ID: orcid.org/0000-0002-1500-2717 
